\title{
Maurice Barrès, Les déracinés
}

\section{Ida Merello}

\section{(2) OpenEdition}

\section{Journals}

\section{Edizione digitale}

URL: https://journals.openedition.org/studifrancesi/38093

DOI: 10.4000/studifrancesi.38093

ISSN: 2427-5856

\section{Editore}

Rosenberg \& Sellier

\section{Edizione cartacea}

Data di pubblicazione: 15 décembre 2004

Paginazione: 637-638

ISSN: 0039-2944

\section{Notizia bibliografica digitale}

Ida Merello, «Maurice Barrès, Les déracinés», Studi Francesi [Online], 144 (XLVIII | |II) | 2004, online da 30 novembre 2015, consultato il 08 mai 2021. URL: http://journals.openedition.org/studifrancesi/ 38093 ; DOI: https://doi.org/10.4000/studifrancesi.38093

\section{Questo documento è stato generato automaticamente il 8 mai 2021.}

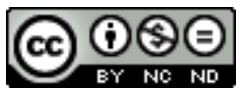

Studi Francesi è distribuita con Licenza Creative Commons Attribuzione - Non commerciale - Non opere derivate 4.0 Internazionale. 


\title{
Maurice Barrès, Les déracinés
}

\author{
Ida Merello
}

\section{NOTIZIA}

MAURICE BARRÈs, Les déracinés, Edition établie, présentée et annotée par Jean-Michel WITTMANN et Emmanuel GODO, Paris, Champion 2004, pp. 486.

1 Pregevole edizione dell'opera di Barrès, preceduta da un'ampia introduzione che offre un'ottima esegesi critica. Gli autori mettono in rapporto il progetto del romanzo con l'esperienza biografica del fallimento delle mire politiche di Barrès, per situare però poi subito il volume nel cuore della storia letteraria, con particolare attenzione all'intertestualità, ai modelli esibiti (il Le Sage di Gil Blas, Stendhal), ma soprattutto a Balzac, che rimane il modello di riferimento sia per il realismo dell'impostazione che per il suo Rastignac. Rastignac infatti costituisce per Barrès un termine di paragone esplicito con il proprio personaggio, François Audiat, che ne rappresenta la versione più cerebrale. Peraltro l'introduzione ha il merito di sottolineare con forza anche l'originalità della concezione narrativa di Barrès, che utilizza insieme spunti autobiografici e documentazione di cronaca per costruire un'opera - comunque di finzione- che si situa alla confluenza di naturalismo e decadentismo. Anche l'aspetto didattico è preso in considerazione, ossia la volontà di presentarsi come un affresco istruttivo della Francia dopo la disfatta del 1870, grazie alla creazione di personaggi dai profili sociologici e ideologici molto marcati, che mettono in scena tutti i vizi dell'età decadente: pessimismo, nichilismo, egoismo, individualismo, cosmopolitismo, cerebralità. Molto utile anche un'attenzione alla recezione critica dell'opera, con particolare attenzione ai contemporanei e ai critici della prima metà del secolo. 